\title{
Cropland Soil Salinization and Associated Hydrology: Trends, Processes and Examples
}

\author{
Uri Nachshon \\ Institute of Soil, Water and Environmental Sciences, Agricultural Research Organization, the Volcani Research \\ Center, Bet-Dagan 50250, Israel; urina@volcani.agri.gov.il
}

Received: 3 July 2018; Accepted: 1 August 2018; Published: 3 August 2018

\begin{abstract}
While global food demand and world population are rapidly growing, land potential for cropping is steadily declining due to various soil degradation processes, a major one of them being soil salinization. Currently, approximately $20 \%$ of total cropland and $33 \%$ of irrigated agricultural land are salinized as a result of poor agricultural practices and it is expected that by 2050, half of the croplands worldwide will become salinized. Thus, there is a real need to better understand soil salinization processes and to develop agricultural practices that will enable production of the needed amount of food to feed humanity, while minimizing soil salinization and other degradation processes. The major sources of solutes in agricultural environments are: (i) the soil itself, and the parent geological material; (ii) shallow and salt rich groundwater; and (iii) salt rich irrigation water. The salinization of soil is a combination of transport of solutes towards the root zone to replenish evaporation and transpiration and limited washing of the soil by rain or irrigation. Therefore, most salinized soils are present in arid and semi-arid environments where precipitation is low and evaporation is high. In this manuscript, examples of soil salinization processes from croplands around the world will be presented and discussed to bring attention to this important topic, to present the latest scientific insights and to highlight the gaps that should be filled, from both scientific and practical perspectives.
\end{abstract}

Keywords: soil salinization; irrigation; salt transport

\section{Introduction}

Soil is one of the most important and essential resources on the globe; however its importance is somewhat underestimated, especially in political and decision making circles [1,2]. The lack of good quality soil risks the supply of food and fibre, of clean fresh water, biodiversity and the overall protection of the ecosystem. It also reduces the potential of soil to act as a sink in the carbon cycle and may remove a central platform for the production of renewable energy sources [3]. Despite its economic and environmental importance, soil is continuously being lost globally due to various degradation processes, with modern agriculture being a main cause of these. This is demonstrated by the fact that more than $50 \%$ of agricultural soils are moderately or highly degraded while less than one third of natural soils are exposed to degradation processes [4]. Soil degradation and loss of soil fertility are mainly a result of soil erosion, loss of soil organic carbon and compaction, alkalization and salinization $[2,4,5]$. The latter is a major soil degradation process that is highly affected by hydrological processes [6], and it will be the focus of this paper.

Population growth and rising economic prosperity result in an increased demand for energy, food, and water [7-9]. Consequently, our natural resources of soil and water are in short supply and overused. It is estimated that by 2050, the world population will surpass 9.5 billion people and an increase of $60 \%$ in our food production will be needed to feed them, assuming food consumption and diet will not dramatically change by then [10]. Consequently, unless food production efficiency 
improves, more cropland areas will be needed to support the expected increased demand in food consumption. Montanarella and Vargas [11] stated that if consumption patterns in emerging economies keep on developing the way they do today and demand for resources keeps on growing, by 2050 we will need an additional Earth in order to have sufficient area for cropping to support human food demand.

Even though croplands cover only $12 \%$ of terrestrial regions, with a total area of about $15 \times 10^{6} \mathrm{~km}^{2}$ [12], the potential to convert more land into cropland is limited as most areas are too steep, too wet, too dry, or too cold for commercial growth of crops [13]. Transition of new land to croplands is usually not economical and does not meet ecological and environmental imperatives [14]. Therefore, there is a real need to better understand and to develop sustainable agricultural practices to support human food demands, while minimizing soil degradation processes in general, and salinization in particular. This paper will review the global trends of soil salinization, demonstrate the main mechanisms of soil salinization and associated hydrological processes in cultivated environments by using examples from around the globe, and discuss the challenges of soil salinization in agricultural environments.

\subsection{Global Trends of Soil Salinization in Croplands}

Soil is considered salinized when plants in the soil are negatively affected by salinity and when the electrical conductivity (EC) of saturation extract soil water exceeds $4 \mathrm{dS} / \mathrm{m}$, at $25^{\circ} \mathrm{C}[15,16]$. Six percent of terrestrial land is naturally salinized in a process termed primary soil salinization, in which salt stored in the soil or groundwater is mobilized to the land surface in the development process of a landscape $[9,17,18]$. However, much greater and faster soil salinization processes are observed in cultivated lands where $20 \%$ of total cropland and $33 \%$ of irrigated croplands worldwide are salinized as a result of agricultural practices $[10,14,15]$. This type of soil salinization, a result of anthropogenic activity, is termed secondary soil salinization $[9,18]$.

Irrigated croplands, with a global approximate total area of only $4 \times 10^{6} \mathrm{~km}^{2}$ [19] constitute approximately $25 \%$ of total cropland areas. However, irrigated croplands worldwide, consume about $65 \%$ of all the water used by humans to grow food [14] and produce about $45 \%$ of humanity's food consumption [20]. Therefore, the importance of irrigated croplands in food, water and soil security is very high $[5,12]$. Salinized areas are steadily growing at a rate of $10 \%$ per year and it is estimated that more than $50 \%$ of croplands worldwide will be salinized by 2050 [17]. Naturally, the economic burden of soil salinization is very high, with the global cost of irrigation-induced salinity being in the order of US\$11 billion per year [21].

\subsection{Impact of Soil Salinization on Plants}

The damaging effects of salinity on plant growth are related to: (1) lowering of soil solution osmotic potential; (2) nutritional imbalance; and (3) specific ion effect [22]. The decrease in the osmotic potential between soil porewater and plant root cells, due to increase of soil pore water solute concentration, leads to restrained water uptake by plants and reduces their ability to survive and produce, especially in dry areas [9]. Salinity may also cause nutrient deficiencies or imbalances due to the competition of sodium and chloride with nutrients such as calcium, potassium and nitrate, which are essential for plant growth [23]. Certain solutes which accumulate in the plant with time can negatively affect various biological functions of the plant [24,25]. For example, high concentrations of boron, chloride, sodium and carbonate are toxic for many plants and result in drying of leaves, damage to fruit, and can affect root growth [22,24,25].

For agricultural purposes, the salt tolerance of a crop is described by various response functions that correlate yield reduction to soil salinity. The first correlations that were developed described a linear reduction of yield as salinity increases [26-28]. Later works presented more complicated functions that correlate yield and soil salinity by exponential ratios $[29,30]$ and a combination of two and three linear segments that describe different stages of crop response to salinity [31,32]. Today the 
function of van Genuchten and Hoffman from 1984 [33] is widely used to describe percentile reduction of yield $\left(f_{E C}\right)$ as a function of the actual saturated paste electrical conductivity of the soil $\left(E C_{e}\right)[28,34]$ :

$$
f_{E C}=\frac{1}{1+\left(\frac{E C_{e}}{E C_{50}}\right)^{P}}
$$

where $E C_{50}$, is the saturated paste electrical conductivity of the soil that leads to a $50 \%$ reduction in yield, $P$ is a plant parameter, which for many situations is equal to $3[35,36]$. Typical $E C_{50}$ values of various crops are detailed in the literature [6,34,37]; for example, for selected species of sunflower, melon, tomato, corn, pepper, grape and onion are in the order of $10,7.5,5.5,5,2.5,2.5$, and $3.5 \mathrm{dS} / \mathrm{m}$, respectively [36].

\subsection{Impact of Soil Salinization on Soil Physical and Hydraulic Properties}

The major processes that lead to salt accumulation and precipitation in the soil are evaporation and root uptake. These processes take the porewater out of the soil, while leaving behind the solutes that are dissolved within. Consequently, porewater solute concentration increases until saturation is reached and salt crystals begin to precipitate [38]. Salt precipitation frequently occurs within narrow layers at the upper boundary of evaporation front or near the roots, where water uptake to replenish transpiration is taking action $[39,40]$. When the evaporation front is at the soil-atmosphere interface, the salt accumulates at the soil surface as an efflorescent (above soil surface) or subflorescent crust (below soil surface), depending mainly on salt type [40,41].

Salt precipitation, especially subflorescence precipitation, greatly affects soil mechanical properties as salt crystallization may lead to soil cementation that holds sand and silt particles together and increases the shear strength and stiffness of soil during the drying process [42,43]. On the other hand, in cohesive soils, subflorescence salt crystallization may enhance weathering processes and reduce soil aggregate stability as the crystallized salt at the pores applies pressure against the pore walls that leads to disaggregation [44,45]. Naturally, salt precipitation in the soil pores changes the soil's hydrological properties and reduces percolation and evaporation processes as it reduces matrix porosity, permeability and vapour diffusivity $[40,43,46,47]$. Salt precipitation as efflorescent salt crust has a weaker effect on the physical properties of the soil-matrix itself, as crystallization takes action above the soil surface. Nevertheless, efflorescence salt precipitation strongly affects evaporation since the salt crust acts as a mulching layer above the soil [40,48].

In salt affected soils, when sodium concentration is high enough to interfere with the growth of most crop plants, and in which the sodium adsorption ration (SAR) is greater than 13, the soil is considered as sodic soil [49]. Sodic soils, and in particular soils that contain 2:1 clay minerals such as smectite, are sensitive to the presence of sodium in the exchange complex, which causes them to swell and disperse (deflocculate) when wetted, following rain and irrigation events [45,50,51]. This leads to soil aggregate breakdown and the formation of a crust on top of the soil surface. The crust reduces infiltration rates, increases surface runoff and consequently leads to enhancement of soil erosion and the formation of rills and gullies [51-53].

\section{Soil Salinization Processes and Associated Hydrological Processes}

The nature of salt transport in porous media is highly affected by surface and subsurface water flow processes which transport the solutes within the system. These processes will be discussed herein and examples from the Canadian prairies, Israel and Inner Mongolia in China (Figure 1) will be introduced to present soil salinization processes, mechanisms and associated hydrological processes. These regions were selected as they are important agricultural areas that have been exposed to soil salinization over recent years due to natural and anthropogenic processes. 


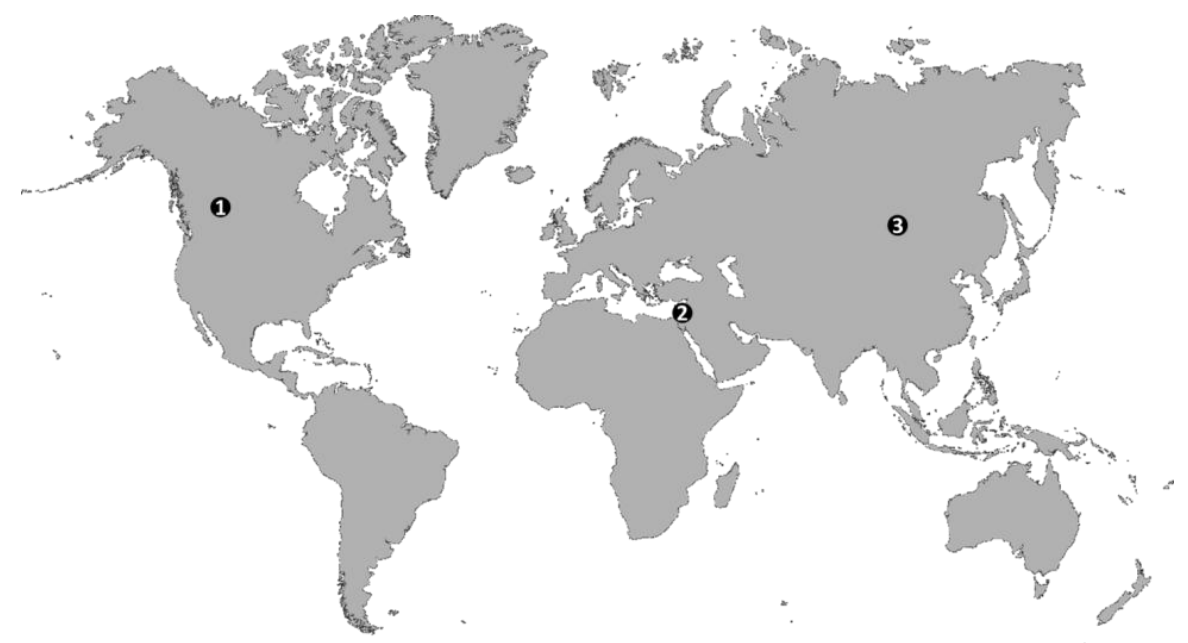

Figure 1. Location of discussed examples of soil salinization from (1) the Canadian prairies; (2) Israel; and (3) Inner Mongolia, China.

\subsection{Salt Transport}

The term "salt transport" is widely used in the literature to describe translocation of salt from one point to another [54-57], but this is a misleading term as solute transport is the mechanism that translocates salt in porous media in general, and agricultural environments in particular. Transport of salt as a solid mineral is possible by the drifting of small salt particles with the wind [9] but this mechanism is meaningful only over long time scales and distances [58], much greater than those relevant for agricultural environments.

Salt, which is formed by the reaction of an acid and a base, is found in soils as an electrically neutralized mineral composed of positive and negative ions that are held together by strong electrostatic attraction forces $[59,60]$. Nevertheless, many salts are relatively soluble in water as the strong electrostatic attraction between water dipoles and the anions and cations forming the salt exceeds the attraction force between the ions [59]. Consequently, porewater and surface water may dissolve crystalline salts and transport the solutes in the water by diffusion and with the water by advection $[59,61]$. When the porewater that contains the solutes is consumed by plants or by evaporation, the solute concentration in the water (solution) increases and upon reaching the solubility concentration of a specific salt, crystallization begins and the salt accumulates in the soil as a solid crystal in its new location. If this location is close to the soil surface or the root zone, then it is said that the soil has become salinized.

In order to reduce the risk of soil salinization, it is critical to understand: (1) how the salt got to the location of salinization; and (2) the origin of the salt. In the following examples soil salinization processes are presented to demonstrate various salt (solutes) transport processes and salt origins.

\subsection{Salt Originating from Parent Geological Material}

In many cases soil salinization results from salts that originate from the parent geological material in the salinized region, where changes in environmental conditions have led to migration of the salt to the root zone and soil surface. An example of this is seen in the Canadian prairies where soil and wetland salinization processes have been observed over recent years due to a combination of climate and land use changes [62-66]. The Prairies are the semi-arid glaciated plains of the North American continent, characterized by a hummocky terrain with ephemeral streams and a large number of wetlands marked by seasonal or semi-permanent ponds. The climate is variable between the south (warmer and wetter) and the north (colder and drier), but is generally semi-arid with potential evaporation in the order of 700-800 mm/year and precipitation of about $300-500 \mathrm{~mm} /$ year $[67,68]$. 
The region supports a diverse community of wildlife species, as well as a major agricultural industry, and both are sensitive to the hydrological conditions of the wetlands and salinization processes $[64,66]$.

The geology of the region is dominated by glacial deposits resulting from the Pleistocene continental glaciers which repeatedly covered the region. These deposits are tens to hundreds of meters thick and consist mostly of clay-rich glacial tills, with interspersed deposits of glacio-lacustrine sand and gravel. The till in the region is particularly rich in sulfate, but also calcium and magnesium, which originate from glacial deposits $[66,69]$. The glaciers pulverized large masses of fresh bedrock, rich in pyrite $\left(\mathrm{FeS}_{2}\right)$, clay minerals, calcite $\left(\mathrm{CaCO}_{3}\right)$, and dolomite $\left(\mathrm{CaMg}\left[\mathrm{CO}_{3}\right]_{2}\right)$, over the course of the Pleistocene, which were subsequently exposed to weathering and dissolution by shallow groundwater flow [70]. In the upper part of the glacial till, which is highly fractured, sulfate $\left(\mathrm{SO}_{4}\right)$ is produced by the oxidation of Pyrite. Sulfate together with calcium form gypsum $\left(\mathrm{CaSO}_{4} \cdot 2 \mathrm{H}_{2} \mathrm{O}\right)$, which is a major salt in the prairies [71]. Beside gypsum, other and more soluble sulfate salts are found including mirabilite $\left(\mathrm{Na}_{2} \mathrm{SO}_{4} \cdot 10 \mathrm{H}_{2} \mathrm{O}\right)$, bloedite $\left(\mathrm{Na}_{2} \mathrm{Mg}\left[\mathrm{SO}_{4}\right]_{2} \cdot 4 \mathrm{H}_{2} \mathrm{O}\right)$, and epsomite $\left(\mathrm{MgSO}_{4} \cdot 7 \mathrm{H}_{2} \mathrm{O}\right)$, where the sodium is derived from the local clay by cation exchange processes [66,71]. Other non-sulfate salts that have been observed in the prairies include halite $(\mathrm{NaCl})$ in minor quantities, originating from the parent material, as well as from atmospheric deposition [72].

Even though the prairies soil is rich in salts, the region is fertile and supports a productive agriculture industry, as the root zone soil in most of the region has been leached out of salts over the years. The salts were transported with surface and sub-surface water flows to local and regional depressions. Under stable climatic and land use conditions, the salts in the depressions are seasonally cycled between the water bodies in the depressions and adjacent hillslopes $[65,66]$, leaving the uplands, where most of the agriculture activity occurs, free of salt. However, over recent years an unusual degree of climatic variability has been recorded, including extreme summer rain storms and floods [65]. As a result, wetland ponds and associated groundwater levels became elevated and new surface and sub-surface flow paths formed in the landscape, resulting in transport of salts towards the uplands, putting them and the agricultural activity under risk of salinization [65,73,74]. Figure 2 presents, conceptually, soil salinization by salt which used to be immobile in the deep parts of soil profile and due to changes in groundwater levels is dissolved and transported upward with capillary flow.

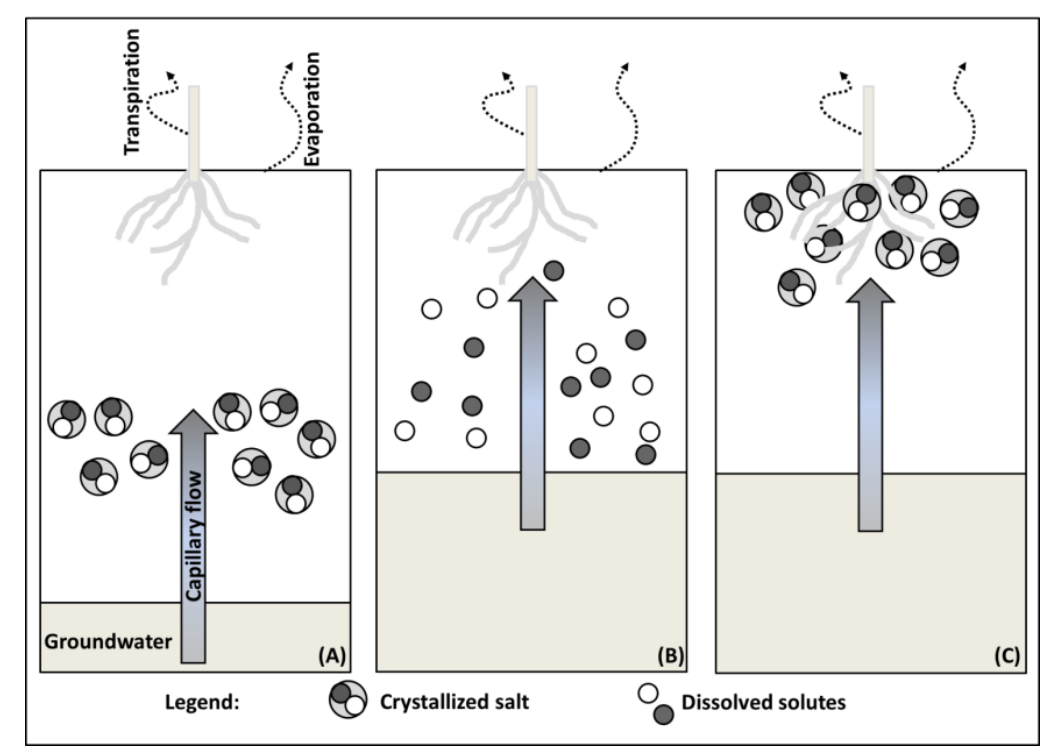

Figure 2. Soil salinization by salt originating from the parent geological material. (A) Initial conditions with salt at deep parts of the soil profile and deep groundwater; (B) Elevated ground water dissolves the salt and solutes are transported upward by capillary flow towards the root zone; (C) Water is evaporated and consumed by the plants while the salts precipitate close to soil surface, resulting in soil salinization. 
On top of climatic changes, the transition from the natural grassland of the prairies to cropland also negatively impacts soil salinization as it affects infiltration and evaporation processes at the root zone. Soil tilling for cultivation tends to decrease the hydraulic conductivity of the upper soil by almost an order of magnitude compared with the natural grassland conditions [70]. Consequently, infiltration and washing of the salts from the upper soil surface downward is reduced. Moreover, most cropland root systems are shallower than those of natural vegetation [70,75], thus shallower evapotranspiration fronts are developed and salt accumulates closer to the ground surface.

\subsection{Salt Originating from Shallow and Salt Rich Groundwater}

A major cause of soil salinization worldwide is the presence of shallow groundwater under agricultural fields, which contains a certain amount of solutes within. Gradually, as water flows upward by capillarity from the water table to replenish evaporative and root water uptake, the solutes accumulate close to the soil surface.

This process is the cause of the formation of many of the salinized soils found in dry areas around the world [43,76-78], with an estimated total area of about $350 \times 10^{4} \mathrm{~km}^{2}$ [9]. An example of soil salinization in an agricultural region, due to the presence of shallow and salty groundwater can be seen in the Gerar wash basin in the Northern Negev desert, Israel (Figure 3).

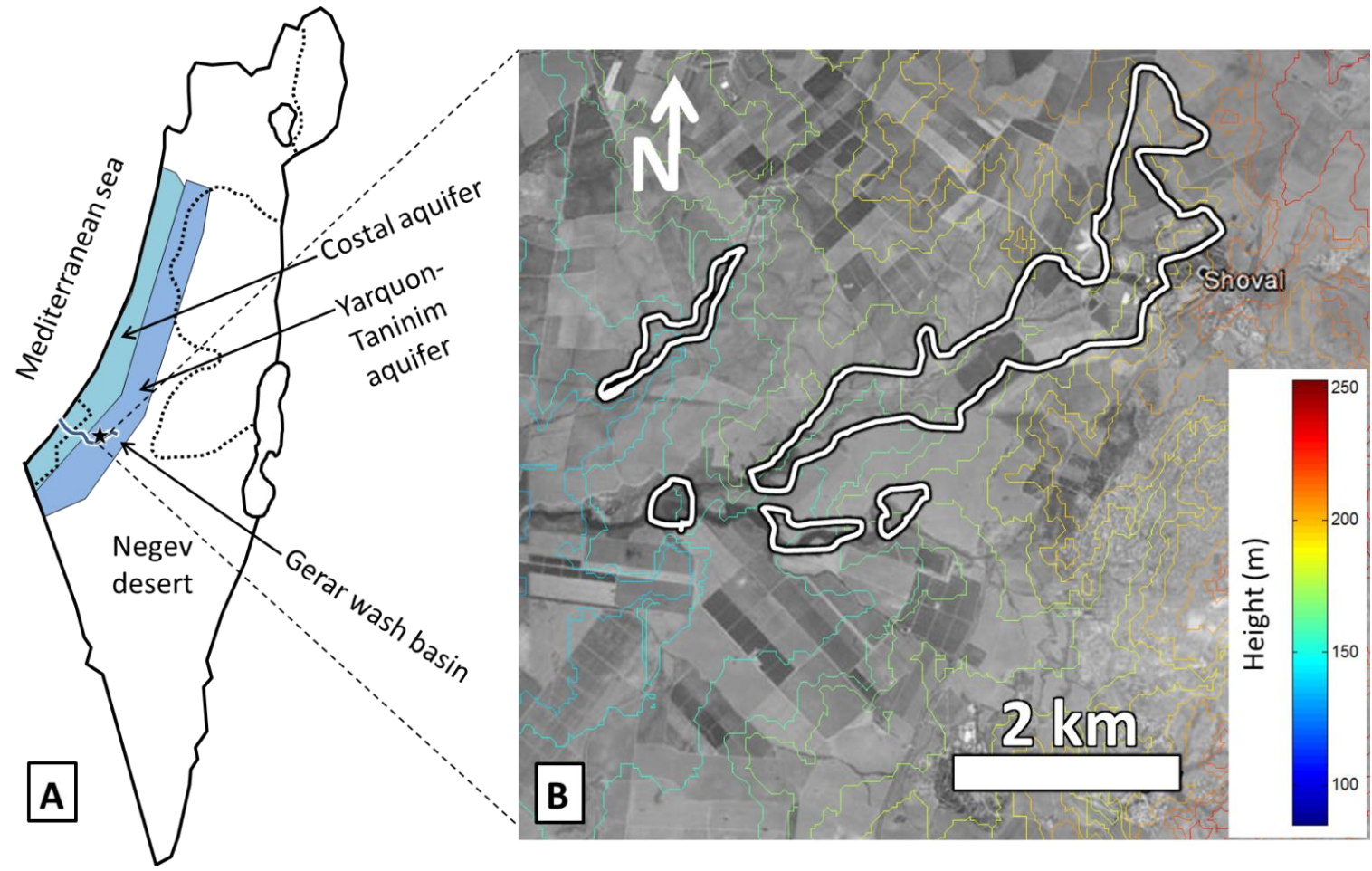

Figure 3. (A) Map of Israel and locations of the Gerar wash basin and associated major aquifers. The black star indicates the region where shallow and saline groundwater is found and a satellite image of this region is seen in (B). The white contours designate areas where ground water is shallower than $2 \mathrm{~m}$ and soil salinization is observed.

The Gerar wash basin (GWB) flows during episodic flood events in winter towards the Mediterranean Sea in the west. The regional climate is semi-arid with an average evaporation of $\sim 2000 \mathrm{~mm}$ /year and low precipitation, in the order of $200 \mathrm{~mm}$ /year concentrated in winter months (data from the Israeli Meteorological Service). The GWB overlies two major aquifers: (1) the Coastal Aquifer in the west; and (2) the Yarquon-Taninim Aquifer in the east. These aquifers are salinized to some extent, mainly in a few sections of their southern parts as a result of sea water intrusions from 
the west and penetration of saline water from the east [79]. In the central and eastern parts of the GWB, groundwater is relatively close to the soil surface and groundwater seepage (springs) can be found in the main flow channel [45]. Water samples from the springs and wells in the basin indicate high salt concentration with $\mathrm{Cl}$ concentration in the order of $5000 \mathrm{mg} / \mathrm{L}[79,80]$ and $E C$ of about $12 \mathrm{dS} / \mathrm{m}$ [45]. The regional topography is undulating and most of the area is cultivated, primarily for wheat, corn and other annual crops. However, while most of the region is fertile and supports a thriving agricultural industry, in the low lands, adjacent to the main stream channel, soil salinization is widely observed where vegetation is absent and in many places an efflorescence salt crust covers the soil (Figure 4).

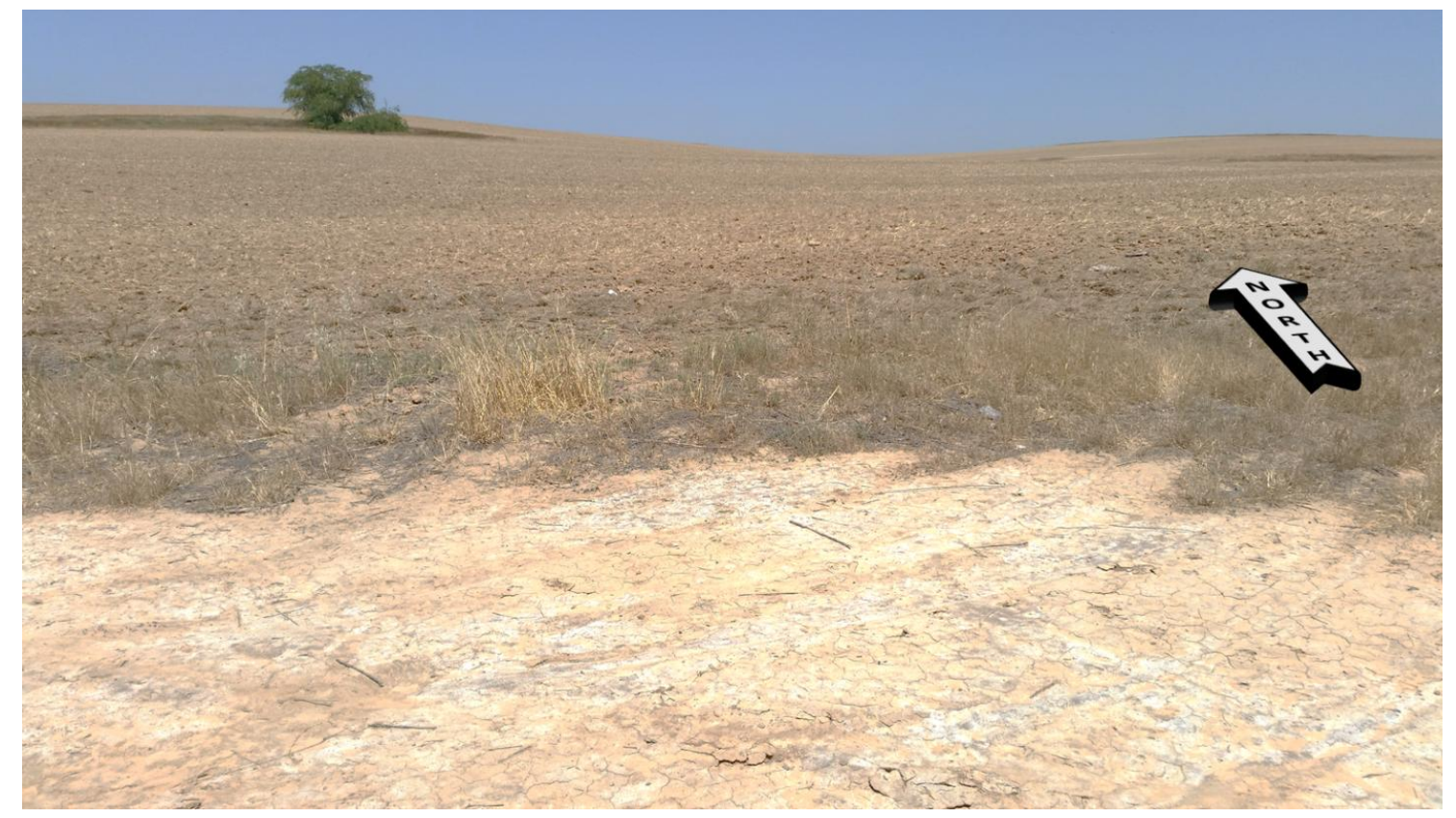

Figure 4. Efflorescence salt crust in the Gerar Basin. Image was taken at the lower parts of a cultivated field adjacent to the main stream channel, which is $\sim 30 \mathrm{~m}$ to the south.

The mechanism that leads to soil salinization in the GWB is capillary rise of the shallow and saline groundwater to the soil surface where the water evaporates and is consumed by plants. Consequently, solute concentration in porewater increases until reaching threshold concentration and precipitation begins. The common soil in the GWB is loess with a sandy clay loam texture which has a typical air entry pressure in the order of $0.5-1 \mathrm{~m}$ and hydraulic conductivity in the order of $1.5 \times 10^{-5} \mathrm{~m} / \mathrm{s}$ at a matric potential of -1 to $-1.5 \mathrm{~m}$ [81]. Therefore, in the low lands, mainly along the main stream channel where groundwater is approximately $1-2 \mathrm{~m}$ below ground surface, the soil is salinized and salt crust is visually observed at the soil surface. In Figure 3B groundwater levels (data from the Israeli Water Authority for summer 2016), were superimposed onto a digital elevation map of the region [82] and onto a satellite image. The white contours designate regions where groundwater is shallower than $2 \mathrm{~m}$ and salinized soil is found. It is evident that currently, the soils that are salinized or under risk of salinization are in the lower parts of the landscape, while the uplands, where most of the agriculture takes place are not affected by the salt. However, measurements done by the Israeli Water Authority over the last 60 years, have shown a continuous rising of groundwater levels at a rate of $1 \mathrm{~m}$ every decade with quick responses in extreme rainy winters. If this trend, whose cause is not clear, does not cease then it is expected that larger and elevated parts of the landscape will be salinized in the near future. Figure 5 presents a conceptual scheme of soil salinization by elevated and saline groundwater. 


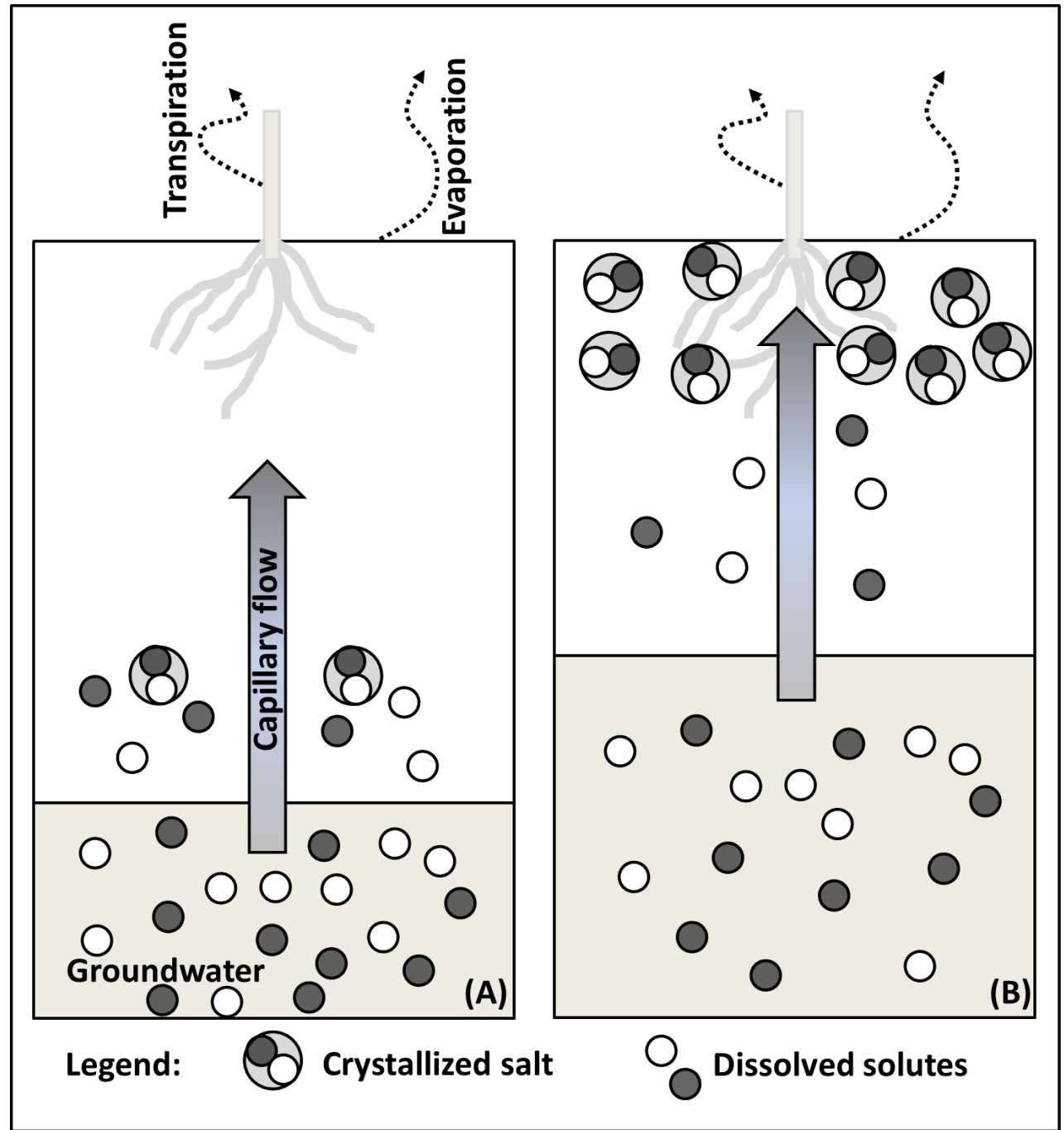

Figure 5. Soil salinization by elevated and saline groundwater. (A) Initial conditions of salt free soil, at the root zone, with deep and salty groundwater. (B) Soil salinization following groundwater rising and transport of solutes to the soil surface by capillary flow.

\subsection{Soil Salinization by Irrigation Water}

In dry areas irrigation is crucial to ensure high yields and profitable agriculture [83]. Currently, almost $90 \%$ of global water consumption is for irrigation purposes, and more than $40 \%$ of crops are produced in irrigated croplands [84]. Modern agriculture in dry areas consumes about 500-1000 mm of water per year while extreme cases may consume up to $2000 \mathrm{~mm}$ [84]. Globally, and in particular in dry areas, high quality water is in short supply and the use of marginal quality water such as brackish groundwater and treated wastewater for irrigation is becoming ever more common [85]. On top of that, overuse of fertilizers through irigation systems (fertigation) may also increase solute concentration in the irrigation water as farmers frequently add fertilizers in quantities much higher than plant demand [86-89]. Consequently, the risk of soil salinization due to unsustainable irrigation practices with water rich in salt is rising [9].

Maximization of crop yields when salinity of irrigation water is high depends on providing plant water needs and evaporative losses, as well as on maintaining minimum soil solution salinity through leaching [90]. The excessive water used to remove salts from the root zone is called the leaching fraction (LF) and is defined as the fraction of water entering the soil and infiltrating beyond the root zone, washing the solutes downward [91]. The minimal LF that will keep the soil salinity below 
a required level is defined as the leaching requirement $(L R) . L R$ is a function of irrigation water $E C$ $\left(E C_{I}\right)$ and required $E C$ of the saturation extract water from the root zone soil $\left(E C_{T}\right)$ to ensure a yield depression lower than $10 \%$ [92]:

$$
L R=\frac{E C_{I}}{5 E C_{T}-E C_{I}}
$$

$E C_{T}$ values for the different crops are found in the literature $[36,93,94]$.

An example of soil salinization by irrigation is observed in the Hetao Irrigation District (HID), in Inner Mongolia, China (Figure 6). The HID is one of the three largest irrigation districts in China, covering an area of $11.2 \times 10^{6} \mathrm{~km}^{2}$, the major part of which $\left(5700 \mathrm{~km}^{2}\right)$ is irrigated land [95]. At the HID, irrigation water consumption is almost $98 \%$ of total water consumption and the region produces more than 35\% of wheat, sunflower and sugar beet in the Inner Mongolia Autonomous Region [96,97], thus it is the most important food base in the region. The HID climatic conditions are arid to semi-arid with mean annual precipitation in the order of $155 \mathrm{~mm}, 70 \%$ of which occurs from July to September and the mean annual pan evaporation is about $2000 \mathrm{~mm}$ [96]. Consequently, the major water source for agriculture in the region is the Yellow River water, where about 5.2 billion cubic meter of water is diverted each year from the river to irrigate this area, through a complex canal system [96,98]. The Yellow River is the second largest river in China (Figure 6) and it supplies water to about 130 million people in nine provinces in Northwest and North China [96,99]. The Yellow River water is fairly good with total dissolved soilids (TDS) and chlorine concentrations in the order of $500 \mathrm{mg} / \mathrm{L}$ and $70 \mathrm{mg} / \mathrm{L}$, respectively [100]. These values are well within the range allowed for irrigation and even drinking.

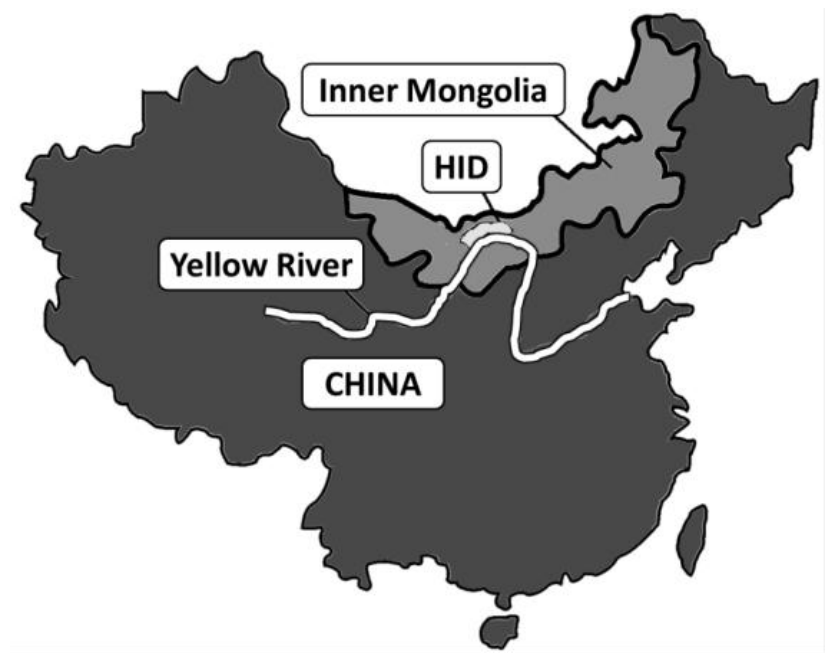

Figure 6. The Hetao irrigation district (HID) in Inner Mongolia, China.

Despite the relatively good quality of the Yellow River water, severe soil salinizationis taking place in the HID, mainly since the 1960s following a great expansion of the irrigation system [95]. The reason for this is the high volume of irrigation water in the region, combined with a high evaporation rate and poor drainge. Due to deficit rainfall in the area, irrigation is required during the entire crop growing season, the dominant irrigation method being surface flood irrigation. The irrigation requirements are in the order of $500 \mathrm{~mm}$ per year $[95,96]$. Considering the TDS of $500 \mathrm{mg} / \mathrm{L}$ measured in the Yellow River water, this means that every year $250 \mathrm{~g}$ of salt is imported to a single square meter of the HID with a total of more than 2.5 million tons of soluble salt imported to the entire HID. Local groundwater level in the region is relatively high, about 1-2 m below ground surface, as a result of seepage from the canal system, percolation from agricultural fields, poor artificial drainage systems and negligible natural deep percolation and lateral flow [96,98]. Consequently, the imported salts from the Yellow River are not washed away from the vadose zone, resulting in salinization of the shallow groundwater and soil, as presented in Figure 7. The elevated groundwater levels and the fine texture 
soils of the region $[96,101]$ also lead to soil waterlogging, on top of their negative contribution to soil salinization $[96,98]$.

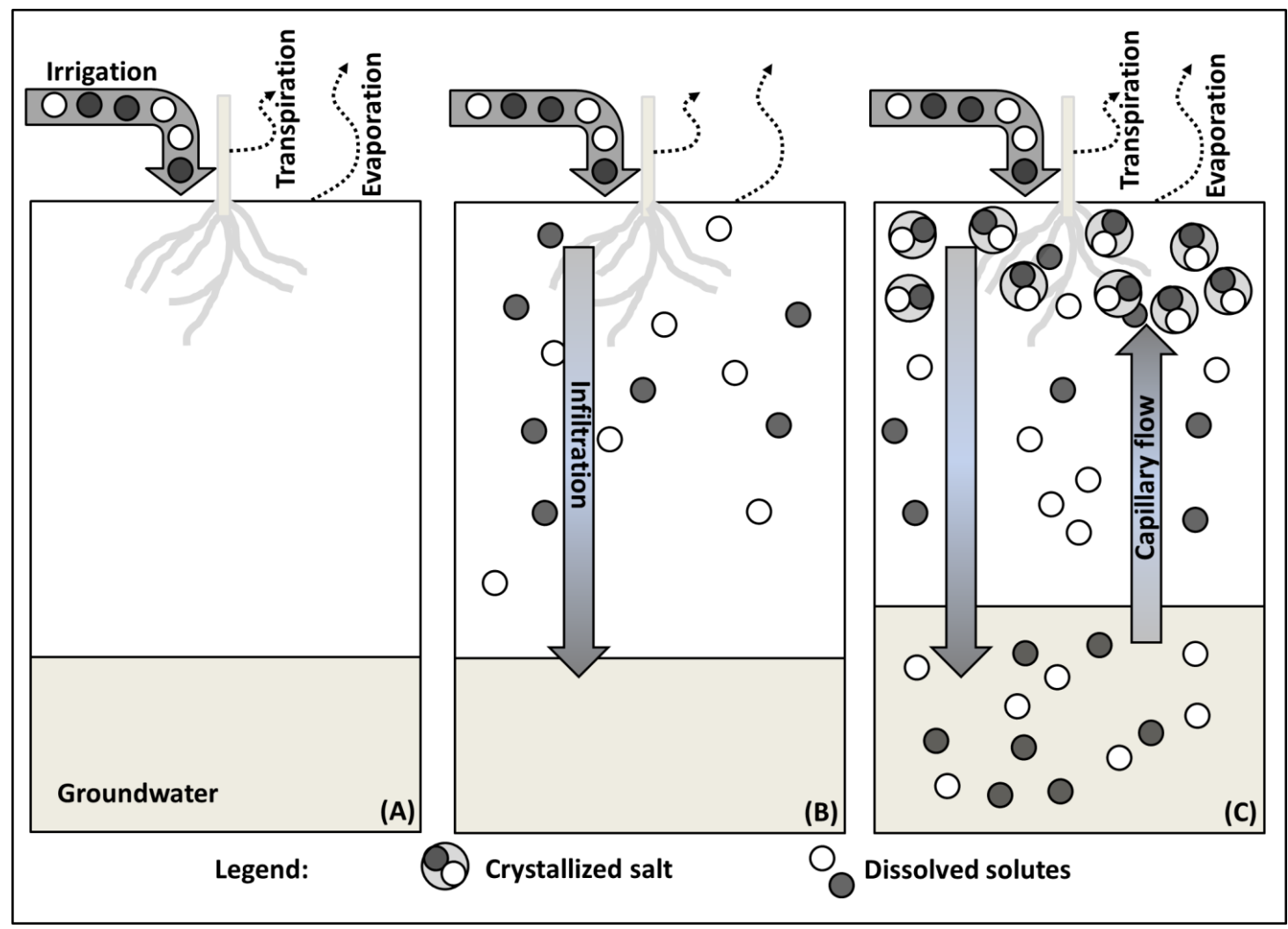

Figure 7. Soil salinization by irrigation water. (A) Initial conditions of salt free soil where irrigation with salty water begins; (B) Soil porewater becomes enriched with solutes; (C) Solutes circulate between the shallow groundwater and soil surface where evapotransporation leads to salt accumulation.

The local farmers at the HID apply technical irrigation at the end of winter (October-November) in order to leach down the salts that accumulated at the root zone during the previous growing season and to enable crop growth during the next growing season [102]. This approach is effective over short time scales but in the long run it is not sustainable as it leads to high transport of solutes into the region and groundwater elevation. More sustainable approaches may include the use of irrigation approaches such as drip irrigation and draining of the fields, as detailed below in Section 4.2.

\section{Key Factors in Soil Salinization}

The examples presented above of soil salinization differ from one another mainly in respect to the source of the salt, which originates from the local parent geological matter, groundwater, or irrigation water. However, even though the three examples are from different parts of the world, they have three fundamental similarities: (i) they are all from dry climatic regions; (ii) soil in all sites has a relatively fine texture and low hydraulic conductivity, which result in limited drainage; and (iii) the groundwater is relatively shallow. Soil salinization can definitely be generated in other setups but these three conditions are the most common features that lead to soil salinization, especially in cultivated regions $[9,103]$.

\subsection{Climatic Conditions}

Dry climate where precipitation is limited and evaporation is high is a key factor for soil salinization. The high evaporative demand results in capillary flow of porewater with the dissolved 
solutes towards soil surface, where evapotranspiration takes place. As the water evaporates or is consumed by plants, the salt accumulates in the soil and precipitates. Rainfall, which in humid regions results in washing of the solutes from the root zone downward, is limited in dry regions. Therefore percolation of rainwater through the soil and the resulting solute leaching downward is limited [6,24]. In the rare occasion of strong rain events, some of the solutes may be leached downward to a limited depth, but as rain ceases porewater flow will be reversed upward to replenish evaporative demands and the solutes will accumulate again at the evaporation front, close to soil surface.

\subsection{Soil Properties}

Soil hydraulic conductivity has a great deal of importance in respect to salt leaching as highly permeable soils such as sandy soil enable effective water percolation and solute leaching, whereas, fine texture soils with low permeability restrict deep perculation and solute transport [104]. In respect to water availability for the plants, fine texture soils are favorable due to their high water holding capacity but they also hold solutes with the water. Additionally, the high capillarity of the fine texture soils results in more effective flow of water from the deeper parts of the soil to the root zone, where evapotranspiration is maximal, thus salt accumulation is elevated [9]. Moreover, fine texture soils tend to swell and disperse (deflocculate) in sodic environments, when wetted during rain and irrigation events $[45,50,51]$. Consequently their permeability is further reduced, surface runoff increases and solute leaching out of the root zone is further reduced [24].

\subsection{Groundwater Levels}

Soil salinization is tightly linked to two groundwater properties: (i) groundwater chemistry; and (ii) groundwater level. Soil salinization occurs in areas of groundwater discharge or elevated water table when salt rich porewater at or near the ground surface, originated from groundwater, continually evaporates and causes minerals to precipitate [105]. The depth of the water table below the surface, together with hydraulic properties of the soil and potential evaporation, control the amount of evaporation at the evaporation front, as they affect capillary water flow from the water table upward. Usually, for groundwater levels deeper than 2-3 m, depending on soil properties, evaporation and resulted salt accumulation will be minor as capillary rise to the evaporation front is negligible $[9,105]$. The chemistry of groundwater is important as the chemical composition of groundwater and solute concentrations will affect the rates of salt accumulation in the root zone and salt mineralogy.

\section{Coping with Soil Salinization in Agricultural Regions}

Like many other problems, the best way of coping with soil salinization is to prevent it by using good quality water and good quality soils. However, as aforementioned, good quality water and soil are in short supply in many areas, especially in dry areas, where the need for irrigation is high, precipitation is low and surpassed by evapotranspiration. Therefore, there is a real need to find ways to improve agricultural and irrigation practices in order to enable flourishing and sustainable agriculture in salt rich environments.

\subsection{Leaching}

Currently, the common practice to cope with salty water irrigation is to leach the salts downward beyond the root zone, by the use of excess water [90,91]. While high LF leads to favorable growing conditions for the plant and maximizes yield, it has negative impacts associated with water conservation and groundwater pollution [106], therefore it is crucial to use optimal $L R$ values. Recently, several models have been developed and are in use to evaluate the effect of leaching on yield, solute transport and optimization of $L R$, such as SWAP (Soil-Water-Atmosphere-Plant) [107], HYDRUS [108,109], and ANSWER (Analytical Salt-Water) [34]. Nevertheless, in practice most farmers do not use these models as they are too complicated for the layman. 
A recent work by Berezniak et al. [110] has shown that when using drip irrigation with salty water, solute leaching from the root zone can be improved by replacing a limited volume of soil $\left(\sim 20 \times 20 \times 20 \mathrm{~cm}^{3}\right)$, with soil of a coarser texture compared to the environment, just below the dripper emitter, where the roots are developing. The coarse soil volume provides a region in which the roots can develop in relatively salt free conditions due to the high permeability (thus leaching) of the coarse domain. In regular field conditions, the soil is homogeneous and water and solutes from beyond the root zone may flow by capillarity into the root zone to replenish evapotranspiration. In the manipulated texture setup, as proposed by Berezniak et al. [110], the sharp interface between the fine texture soil (ambient) and the coarse texture soil, that acts as a capillary barrier, prevents the return of solutes back into the central part of the root zone. This method is still not in practical use but with more study, and development of the needed agro-technical machines, it may be a possible management practice for controlling water and salinity in irrigated fields, while reducing $L R$, saving water, and reducing the risk of soil (and groundwater) salinization [111].

\subsection{Drainage}

As demonstrated in the examples above, restricted drainage, which may be caused by the low permeability of the soil or the presence of a high groundwater table, usually contributes to soil salinization $[9,112]$. Consequently, artificial subsurface drainage of salinized croplands may improve and even reclaim salinized soils, as well as solving associated problems of waterlogging $[10,113,114]$.

An artificial drainage system may consist of any combination of horizontal and vertical subsurface drainage pipes, relief wells, pumping wells and digging of drain ditches, in order to control groundwater levels and to impose efficient drainage of the root zone following rain and irrigation events [114-116]. It is now well understood that appropriate drainage may significantly improve soil salinization problems in irrigated croplands. Nevertheless, more than two thirds of the areas worldwide needing drainage have not been drained yet [114,117]. The use and installation of drainage systems has to be promoted by the nation and decision makers, as many farmers do not have the resources for implementing such a system, especially in developing countries $[113,118]$. Scientifically, more research is needed to better understand the connections between soil salinity, water salinity, depth of drainage, groundwater levels and crop yield [114].

In clayey-sodic soils, rain water infiltration and drainage could be restricted due to soil swelling and dispersion, as a result of the high concentrations of $\mathrm{Na}$ in the soil solution or the exchange phase $[119,120]$, which results in aggregate breakdown and soil crusting [51-53]. Reclamation of sodic soils and drainage improvement are done by removal of $\mathrm{Na}$ from the soil exchange sites into soil solutions by divalent cations, usually $\mathrm{Ca}[119,121,122]$.

Gypsum $\left(\mathrm{CaSO}_{4} \cdot 2 \mathrm{H}_{2} \mathrm{O}\right)$ is the most common soil amendment used to reclaim sodic soils $[123,124]$ as it contributes $\mathrm{Ca}$ to the system when being dissolved into porewater. Nevertheless, many other chemicals are being used to supply cations to the soil by various means, such as sulfur, sulfuric acid $[125,126]$, and polyhalite $[112,119]$. Recently, phytoremediation has been considered as an alternative to chemical amendments. This method works on the principle of dissolution of native calcite to supply soluble calcium by facilitating changes in root zone partial pressure of $\mathrm{CO}_{2}$ by plants [127]. Organic soil amendments such as biochar, biosolids compost, and green waste compost [119] are also used to improve the soil's structure, aggregate stability, hydraulic conductivity and as contributors of Ca.

\subsection{Biological Solutions}

Another approach to cope with soil salinization is not to invest resources in reducing and preventing soil salinization, but rather to use halophyte species for agriculture. This includes domestication of wild species that are resilient to salinity and produce edible yield and valuable biomass [128], and developing and breeding of crops known to be more salt-tolerant [129]. For example, a potential oil-seed crop that can be used in salty water is Salicornia bigelovii, which can be 
irrigated with ocean water and may produce a yield almost two times greater than sunflower [128]. Salicornia bigelovii is considered one of the most promising halophytic species to be grown in salt rich environments such as coastal lines. However, a suitable germplasm still needs to be identified, domesticated and developed in order to be widely used in modern agriculture [130]. The development of halophytic species to produce food, fiber, and fuel has great potential as it will generate new croplands in areas that currently are not suitable for agriculture such as the coastal lines and very saline inland areas. Nevertheless, the research and development of these species is in its infancy and more work is needed [128-131].

Another use of halophyte plants is to reclaim saline soil. This relies on the concept that some plants may extract salt from the soil with the consumed water and accumulate it in their tissues [11,132]. This type of soil reclamation, termed phytoremediation, has the potential to become a cost-effective and environmentally sound technology for remediation of salt impacted soils, if it is properly developed [11]. For example, Ravindran et al. [132] demonstrated that the plants Suaeda maritima and Sesuvium portulacastrum removed approximately $500 \mathrm{~kg}$ of $\mathrm{NaCl}$ from a $0.01 \mathrm{~km}^{2}$ salinized field over a period of 4 months. As for acclimation of the common agricultural crops to salt conditions; this is also a promising field, yet there is still a lot to develop and study before transgenic plants and developed species will be resilient enough to salinity and productive enough to be considered for use in modern agriculture $[129,131,133]$.

\subsection{Water Desalination and Blending}

Saline water desalination is growing rapidly with a marked improvement in the technology's efficiency during the last decade [134]. Water desalination technologies offer a potential remedy to soil salinization in irrigated croplands by allowing farmers to use treated saline water from various sources, including saline groundwater, ocean water, or treated waste water $[135,136]$. Nevertheless, the cost of desalinized water may be too high and not justified to be used for economic reasons. However, a recent study of Kaner et al. [34], conducted in Israel, has shown that for salinity-sensitive and high value crops the use of desalinized water justifies the cost of desalination, even in small scale and private desalinization systems. Similar conclusions were reported also for banana plantations where the use of the desalinated water resulted in increased yield, even compared to the use of the local tap (drinking) water that contained a small amount of solutes [137].

Another option to improve water quality in a simple manner is to blend water with different degrees of salinity, in order to generate an irrigation water composition that will not result in soil salinization [118]. The blend can be applied by mixing relatively good quality water with salty water prior to irrigation or by irrigating the field with water at different degrees of salinity at different times. By doing so, salt that accumulated at the root zone while irrigating with the salty water is leached down when applying irrigation with good quality water [138].

\subsection{Cultivation Practices}

Soil salinization can be moderated by proper field cultivation practices. Crop rotation, which is the practice of growing a series of different types of crops in the same area in sequenced seasons may be a sustainable approach to cope with soil salinization $[87,118]$. By alternating crops, different irrigation and fertilization regimes are implemented and by that the farmers can reduce the amount of solutes transported into the field. Moreover, by including rain fed crops in the rotation, effective leaching of the solutes can be achieved by the rain events while no more solutes are transported into the field by irrigation water. Another practice that may help to accommodate soil salinization is the addition of organic matter to the soil $[139,140]$. Organic matter stabilizes soil structure, prevents dispersion and swelling processes and maintains a high infiltration capacity [141], which improves soil leaching and solute transport beyond the root zone.

For raised beds irrigated with salty water, a recent study by Devkota et al. [142] showed that flood irrigation at every second furrow supports salt removal from the root zone due to preferential 
water flow from the wet region to the dry region. The authors have shown that irrigation in alternating furrows could possibly be more beneficial to farmers if cultivating salt-sensitive crops on the side of the irrigated furrows and a salt-tolerant crop, cotton for example, on the side of the dry furrows. However, further research is still needed in order to better understand and optimize this method. In general, any cultivation practice that maintains high infiltration capacity of the soil is favorable in respect to soil salinity, ensuring effective leaching of the solutes from the root zone.

\section{Summary}

As detailed in this manuscript, soil is a valuable and limited resource with a very long formation period, in the order of thousands of years [143], therefore, if not treated in a sustainable manner, in few decades it will be in short supply. Consequently, the world population will not have sufficient fertile soils to grow the food it needs. Among the many soil degradation and fertility loss processes, such as soil erosion, loss of soil organic carbon, compaction and urbanization; soil salinization and alkalization are major processes that have to be addressed.

Hydrological processes greatly affect solute transport and salt accumulation in soils, and understanding of these processes is crucial. Since hydrological and growing conditions are varied for different fields, worldwide, it is impossible to formulate a generic strategy to manage and cope with soil salinization. Nevertheless, common guidelines to cope with salinized soil, to reduce the risk of soil salinization and sometimes even to remediate salinized soils can be drawn, as detailed in Figure 8 . The basic concept is to detect the origin of the salt and its transport mechanisms and to find plausible ways to either eliminate the salt at its origin or to prevent it from reaching the root zone.

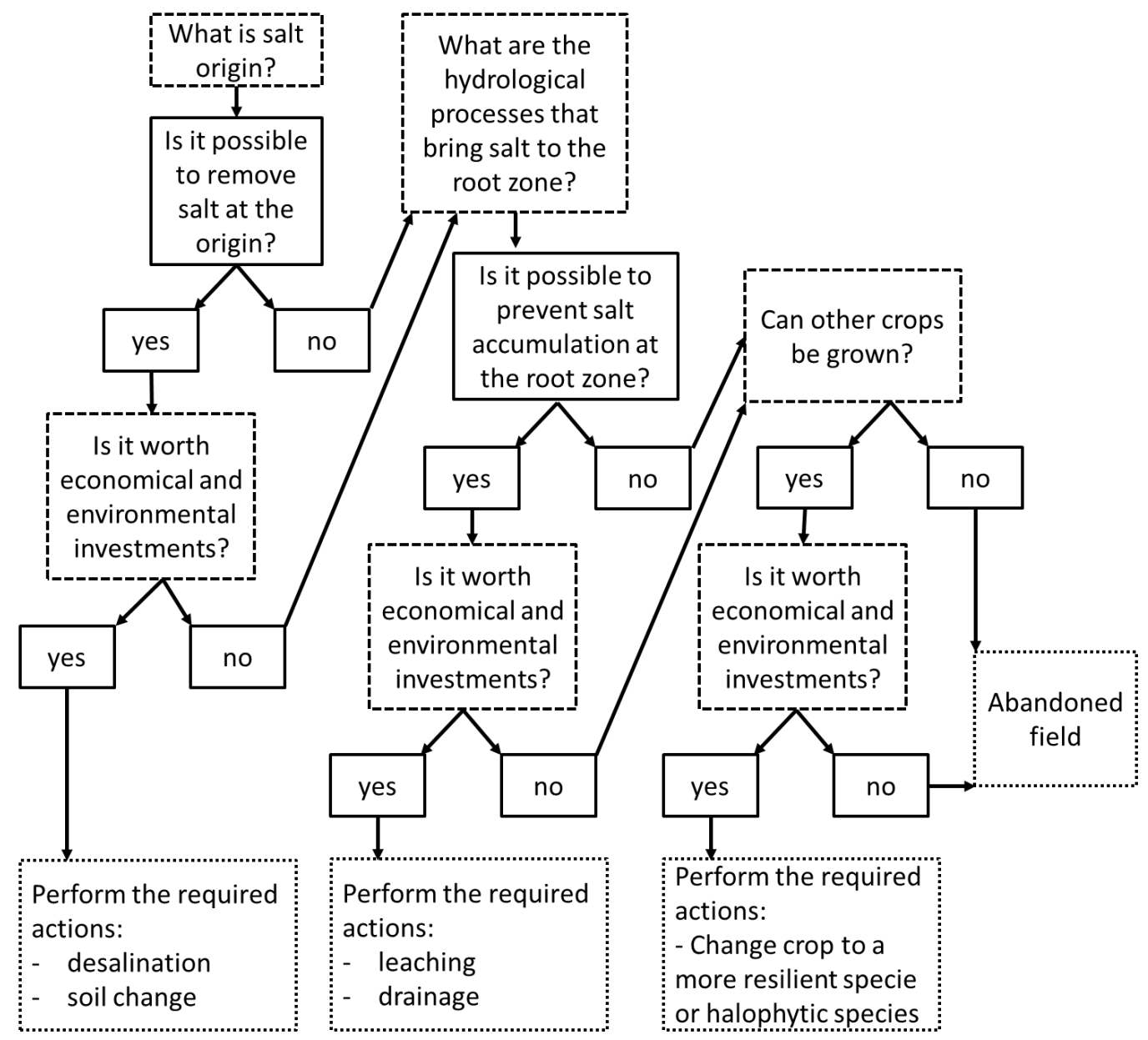

Figure 8. Decision making flow-chart to cope with soil salinization. 
The examples presented in this paper of soil salinization from around the world, demonstrate the basic and common concepts of soil salinization in cropland regions and indicate that dry climatic conditions, high groundwater levels, and the quality of irrigation water are key factors affecting soil salinization. Nations, politicians, and decision makers have to take the management of soil resources more seriously in order to avoid a fatal situation where in the near future we might have not enough soils to grow our food in.

Funding: This research received no external funding.

Conflicts of Interest: The authors declare no conflicts of interest.

\section{References}

1. Herrick, J.E. Soil quality: An indicator of sustainable land management? Appl. Soil Ecol. 2000, 15, 75-83. [CrossRef]

2. Davies, J. The business case for soil. Nature 2017, 543, 309-311. [CrossRef] [PubMed]

3. McBratney, A.; Field, D.J.; Koch, A. The dimensions of soil security. Geoderma 2014, 213, 203-213. [CrossRef]

4. Foley, J.A.; Defries, R.; Asner, G.P.; Barford, C.; Bonan, G.; Carpenter, S.R.; Chapin, F.S.; Coe, M.T.; Daily, G.C.; Gibbs, H.K.; et al. Global Consequences of Land Use. Science 2005, 309, 570-574. [CrossRef] [PubMed]

5. Koch, A.; Mcbratney, A.; Adams, M.; Field, D.; Hill, R.; Crawford, J.; Minasny, B.; Lal, R.; Abbott, L.; O'Donnell, A.; et al. Soil Security: Solving the Global Soil Crisis. Glob. Policy 2013, 4, 434-441. [CrossRef]

6. Farifteh, J.; Farshad, A.; George, R.J. Assessing salt-affected soils using remote sensing, solute modelling, and geophysics. Geoderma 2006, 130, 191-206. [CrossRef]

7. Reisch, L.; Eberle, U.; Lorek, S. Sustainable food consumption: An overview of contemporary issues and policies. Sustain. Sci. Pract. Policy 2013, 9, 7-25. [CrossRef]

8. Wild, A. Soils, Land and Food: Managing the Land during the Twenty-First Century; Cambridge University Press: Cambridge, UK, 2003.

9. Rengasamy, P. World salinization with emphasis on Australia. J. Exp. Bot. 2006, 57, 1017-1023. [CrossRef] [PubMed]

10. Singh, A. Soil salinization and waterlogging: A threat to environment and agricultural sustainability. Ecol. Indic. 2015, 57, 128-130. [CrossRef]

11. Hasanuzzaman, M.; Nahar, K.; Alam, M.; Bhowmik, P.C.; Hossain, A.; Rahman, M.M.; Narasimha, M.; Prasad, V.; Ozturk, M.; Fujita, M. Potential Use of Halophytes to Remediate Saline Soils. BioMed Res. Int. 2014, 2014, 589341. [CrossRef] [PubMed]

12. Thenkabail, P.S.; Hanjra, M.A.; Dheeravath, V.; Gumma, M. A holistic view of global croplands and their water use for ensuring global food security in the 21st century through advanced remote sensing and non-remote sensing approaches. Remote Sens. 2010, 2, 211-261. [CrossRef]

13. Kendall, W.H.; Pimentel, D. Constraints on the expansion of the global food supply. Ambio 1994, 1, 198-205.

14. Thenkabail, P.S. Global croplands and their importance for water and food security in the twenty-first century: Towards an ever green revolution that combines a second green revolution with a blue revolution. Remote Sens. 2010, 2, 2305-2312. [CrossRef]

15. Shrivastava, P.; Rajesh, K. Soil salinity: A serious environmental issue and plant growth promoting bacteria as one of the tools for its alleviation. Saudi J. Biol. Sci. 2015, 22, 123-131. [CrossRef] [PubMed]

16. Peck, A.J. Salinization of Non-Irrigated Soils and Associated Streams: A Review. Aust. J. Soil Res. 1978, 16, 157-168. [CrossRef]

17. Jamil, A.; Riaz, S.; Ashraf, M.; Foolad, M.R. Gene expression profiling of plants under salt stress. Crit. Rev. Plant Sci. 2011, 30, 435-458. [CrossRef]

18. Zhou, D.; Lin, Z.; Liu, L.; Zimmermann, D. Assessing secondary soil salinization risk based on the PSR sustainability framework. J. Environ. Manag. 2013, 128, 642-654. [CrossRef] [PubMed]

19. Thenkabail, P.; Lyon, G.J.; Turral, H.; Biradar, C.M. Remote Sensing of Global Croplands for Food Security; CRC Press-Taylor and Francis Group: Boca Raton, FL, USA; London, UK; New York, NY, USA, 2009.

20. Thenkabail, P.S.; Biradar, C.M.; Noojipady, P.; Dheeravath, V.; Li, Y.J.; Velpuri, M.; Gumma, M.; Reddy, G.P.O.; Turral, H.; Cai, X.L.; et al. Global irrigated area map (GIAM), derived from remote sensing, for the end of the last millennium. Int. J. Remote Sens. 2009, 30, 3679-3733. [CrossRef] 
21. Food and Agriculture Organization of the United Nations (FAO). Management of Irrigation-Induced Saltaffected Soils; FAO: Rome, Italy, 2005.

22. Ashraf, M.; Harris, P.J.C. Potential biochemical indicators of salinity tolerance in plants. Plant Sci. 2004, 166, 3-16. [CrossRef]

23. Hu, Y.; Schmidhalter, U. Drought and salinity: A comparison of their effects on mineral nutrition of plants. J. Plant Nutr. Soil Sci. 2005, 168, 541-549. [CrossRef]

24. Bernstein, L. Effects of salinity and sodicity on plant growth. Annu. Rev. Phytopathol. 1975, 13, $295-312$. [CrossRef]

25. Munns, R.; Tester, M. Mechanisms of Salinity Tolerance. Annu. Rev. Plant Biol. 2008, 59, 651-681. [CrossRef] [PubMed]

26. Palmer, A.E. Kind, position and toxicity of alkali salts in certain Alberta irrigated soils. Sci. Agric. 1937, 18, 132-140.

27. Magistad, O.C.; Ayers, A.D.; Wadleigh, C.H.; Gauch, H.G. Effect of salt concentration, kind of salt, and climate on plant growth in sand cultures. Plant Physiol. 1943, 18, 151. [CrossRef] [PubMed]

28. Steppuhn, H.; Van Genuchten, M.T.; Grieve, C.M. Root-zone salinity: I. Selecting a product-yield index and response function for crop tolerance. Crop Sci. 2005, 45, 209-220. [CrossRef]

29. Weibull, W. A statistical distribution function of wide application. J. Appl. Mech. 1951, 18, $293-297$.

30. Steppuhn, H.; Wang, H.; Gan, Y. Evaluating Russian wild ryegrass emergence from saline seedbeds using the Gompertz function. Can. Agric. Eng. 1998, 40, 241-247.

31. Maas, E.V.; Hoffman, G.J. Crop salt tolerance-current assessment. J. Irrig. Drain. Div. 1977, 103, $115-134$.

32. Van Genuchten, M.T. Analyzing Crop Salt Tolerance Data: Model Description and User's Manual; USSL: Washington, DC, USA, 1983.

33. Van Genuchten, M.T.; Hoffman, G.J. Analysis of crop production. In Soil Salinity under Irrigation; Shainberg, I., Shalhevet, J., Eds.; Springer: New York, NY, USA, 1984; pp. 258-271.

34. Kaner, A.; Tripler, E.; Hadas, E.; Ben-Gal, A. Feasibility of desalination as an alternative to irrigation with water high in salts. Desalination 2017, 416, 122-128. [CrossRef]

35. Van Genuchten, M.T.; Gupta, S.K. A reassessment of the crop response function. J. Indian Soc. Soil Sci. 1993, 41, 730-737.

36. Shani, U.; Ben-Gal, A.; Tripler, E.; Dudley, L.M. Plant response to the soil environment: An analytical model integrating yield, water, soil type, and salinity. Water Resour. Res. 2007, 43, 1-12. [CrossRef]

37. Royo, A.; Aragüés, R. Salinity-yield response functions of barley genotypes assessed with a triple line source sprinkler system. Plant Soil 1999, 209, 9-20. [CrossRef]

38. Espinosa, R.M.; Franke, L.; Deckelmann, G. Phase changes of salts in porous materials: Crystallization, hydration and deliquescence. Constr. Build. Mater. 2008, 22, 1758-1773. [CrossRef]

39. Nachshon, U.; Weisbrod, N.; Dragila, M.I.; Grader, A. Combined evaporation and salt precipitation in homogeneous and heterogeneous porous media. Water Resour. Res. 2011, 47, 1-16. [CrossRef]

40. Nachshon, U.; Weisbrod, N. Beyond the Salt Crust: On Combined Evaporation and Subflorescent Salt Precipitation in Porous Media. Transp. Porous Media 2015, 110, 295-310. [CrossRef]

41. Rodriguez-Navarro, C.; Doehne, E. Salt weathering: Influence of evaporation rate, supersaturation and crystallization pattern. Earth Surf. Process. Landf. 1999, 24, 191-209. [CrossRef]

42. He, J.; Chu, J. Cementation of sand due to salt precipitation in drying process. Mar. Georesour. Geotechnol. 2017, 35, 441-445. [CrossRef]

43. Abduljauwad, S.N.; Al-Amoudi, O.S.B. Geotechnical behaviour of saline sabkha soils. Géotechnique 1995, 45, 425-445. [CrossRef]

44. Amit, R.; Gerson, R.; Yaalon, D.H. Stages and rate of the gravel shattering process by salts in desert Reg soils. Geoderma 1993, 57, 295-324. [CrossRef]

45. Nachshon, U. Seepage weathering impacts on erosivity of arid stream banks: A new conceptual model. Geomorphology 2016, 261, 212-221. [CrossRef]

46. Fujimaki, H.; Shimano, T.; Inoue, M.; Nakane, K. Effect of a Salt Crust on Evaporation from a Bare Saline Soil. Vadose Zone J. 2006, 5, 1246-1256. [CrossRef]

47. Gran, M.; Carrera, J.; Olivella, S.; Saaltink, M.W. Modeling evaporation processes in a saline soil from saturation to oven dry conditions. Hydrol. Earth Syst. Sci. 2011, 15, 2077-2089. [CrossRef] 
48. Zhang, C.; Ling, L.; Lockington, D. Numerical study of evaporation-induced salt accumulation and precipitation in bare saline soils: Mechanism and feedback. Water Resour. Res. 2014, 50, 8084-8106. [CrossRef]

49. Brady, N.C. The Nature and Properties of Soils; Macmillan Publishing Company Incorporated: New York, NY, USA, 1990.

50. Faulkner, H.; Alexander, R.; Teeuw, R.; Zukowskyj, P. Variations in soil dispersivity across a gully head displaying shallow sub-surface pipes, and the role of shallow pipes in rill initiation. Earth Surf. Process. Landf. 2004, 29, 1143-1160. [CrossRef]

51. Shainberg, I.; Letey, J. Response of soils to sodic and saline condtions. Hilgardia 1984, 52, 1-57. [CrossRef]

52. Fitzpatrick, R.W.; Boucher, S.C.; Naidu, R.; Fritsch, E. Environmental consequences of soil sodicity. Aust. J. Soil Res. 1994, 32, 1069-1093. [CrossRef]

53. Tang, Z.; Lei, T.; Yu, J.; Shainberg, I.; Mamedov, A.I.; Ben-Hur, M.; Levy, G.J. Runoff and Interrill Erosion in Sodic Soils Treated with Dry PAM and Phosphogypsum. Soil Sci. Soc. Am. J. 2006, 70, 679-690. [CrossRef]

54. Shokri, N. Pore-scale dynamics of salt transport and distribution in drying porous media. Phys. Fluids 2014, 26, 012106. [CrossRef]

55. Treguier, A.M.; Deshayes, J.; Le Sommer, J.; Lique, C.; Madec, G.; Penduff, T.; Molines, J.M.; Barnier, B.; Bourdalle-Badie, R.; Talandier, C. Meridional transport of salt in the global ocean from an eddy-resolving model. Ocean Sci. 2014, 10, 243-255. [CrossRef]

56. Yang, H.; Chen, Y.; Zhang, F.; Xu, T.; Cai, X. Prediction of salt transport in different soil textures under drip irrigation in an arid zone using the SWAGMAN Destiny model. Soil Res. 2016, 54, 869-879. [CrossRef]

57. Mamoua, K.; Pandit, A.; Heck, H. Stochastic Nature of Salt Mass Transport in Porous Media under Unstable Conditions. Hydrol. Curr. Res. 2017, 8, 278. [CrossRef]

58. Abuduwaili, J.; Gabchenko, M.V.; Junrong, X. Eolian transport of salts-A case study in the area of Lake Ebinur (Xinjiang, Northwest China). J. Arid Environ. 2008, 72, 1843-1852. [CrossRef]

59. Hillel, D. Environmental Soil Physics, 1st ed.; Elsevier: San Diego, CA, USA, 1998; ISBN 9780123485250.

60. Lide, D.R. CRC Handbook of Chemistry and Physics; CRC Press: Boca Raton, FL, USA, 2005; ISBN 0849304792.

61. Leij, F.J.; Genuchten, M.T. van Solute Transport. In Soil Physics Companion; Warrick, A.W., Ed.; CRC Press: Boca Raton, FL, USA, 2001; pp. 189-248.

62. Awada, L.; Lindwall, C.W.; Sonntag, B. The development and adoption of conservation tillage systems on the Canadian Prairies. Int. Soil Water Conserv. Res. 2014, 2, 47-65. [CrossRef]

63. Pennock, D.; Bedard-Haughn, A.; Kiss, J.; van der Kamp, G. Application of hydropedology to predictive mapping of wetland soils in the Canadian Prairie Pothole Region. Geoderma 2014, 235-236, 199-211. [CrossRef]

64. Hayashi, M.; van der Kamp, G.; Rosenberry, D.O. Hydrology of Prairie Wetlands: Understanding the Integrated Surface-Water and Groundwater Processes. Wetlands 2016, 36, 237-254. [CrossRef]

65. Nachshon, U.; Ireson, A.; van der Kamp, G.; Davies, S.R.; Wheater, H. Impacts of climate variability on wetland salinization in the North American prairies. Hydrol. Earth Syst. Sci. 2014, 18, 1251-1263. [CrossRef]

66. Nachshon, U.; Ireson, A.; van der Kamp, G.; Wheater, H. Sulfate salt dynamics in the glaciated plains of North America. J. Hydrol. 2013, 499, 188-199. [CrossRef]

67. Akinremi, O.O.; McGinn, S.M.; Cutforth, H.W. Precipitation trends on the Canadian Prairies. J. Clim. 1999, 12, 2996-3003. [CrossRef]

68. Van der Kamp, G.; Hayashi, M.; Gallén, D. Comparing the hydrology of grassed and cultivated catchments in the semi-arid Canadian prairies. Hydrol. Process. 2003, 17, 559-575. [CrossRef]

69. Van Stempvoort, D.R.; Hendry, M.J.; Schoenau, J.J.; Krouse, H.R. Sources and dynamics of sulphur in weathered till, western glaciated plains of North America. Chem. Geol. 1994, 111, 35-56. [CrossRef]

70. Van der Kamp, G.; Hayashi, M. Groundwater-wetland ecosystem interaction in the semiarid glaciated plains of North America. Hydrogeol. J. 2009, 17, 203-214. [CrossRef]

71. Keller, C.K.; van der Kamp, G.; Cherry, J.A. Hydrogeochemistry of a clayey till: 1. Spatial variability. Water Resour. Res. 1991, 27, 2543-2554. [CrossRef]

72. Hayashi, M.; van Der Kamp, G.; Rudolph, D.L. Mass transfer processes between a prairie pothole and adjacent uplands, 2: Chloride cycle. J. Hydrol. 1998, 207, 56-67. [CrossRef]

73. Mitch, J.W.; Hernandez, M.E. Landscape and climate change threats to wetlands of North and Central America. Aquat. Sci. 2013, 75, 133-149. [CrossRef] 
74. Shook, K.R.; Pomeroy, J.W. Memory effects of depressional storage in Northern Prairie hydrology. Hydrol. Process. 2011, 25, 3890-3898. [CrossRef]

75. Canadell, J.; Jackson, R.B.; Ehleringer, J.B.; Mooney, H.A.; Sala, O.E.; Schulze, E.D. Maximum rooting depth of vegetation types at the global scale. Oecologia 1996, 108, 583-595. [CrossRef] [PubMed]

76. Finstad, K.; Pfeiffer, M.; McNicol, G.; Barnes, J.; Demergasso, C.; Chong, G.; Amundson, R. Rates and geochemical processes of soil and salt crust formation in Salars of the Atacama Desert, Chile. Geoderma 2016, 284, 57-72. [CrossRef]

77. Boutt, D.F.; Hynek, S.A.; Munk, L.A.; Corenthal, L.G. Rapid recharge of fresh water to the halite-hosted brine aquifer of Salar de Atacama, Chile. Hydrol. Process. 2016, 30, 4720-4740. [CrossRef]

78. Tyler, S.W.; Munoz, J.F.; Wood, W.W. The response of playa and sabkha hydraulics and mineralogy to climate forcing. Groundwater 2006, 44, 329-338. [CrossRef] [PubMed]

79. Vengosh, A.; Rosenthal, E. Saline groundwater in Israel: Its bearing on the water crisis in the country. J. Hydrol. 1994, 156, 389-430. [CrossRef]

80. Vengosh, A.; Spivack, A.J.; Artzi, Y.; Ayalon, A. Geochemical and boron, strontium, and oxygen isotopic constraints on the origin of the salinity in groundwater. Water Resour. Res. 1999, 35, 1877-1894. [CrossRef]

81. Gvirtzman, H.; Shalev, E.; Dahan, O.; Hatzor, Y.H. Large-scale infiltration experiments into unsaturated stratified loess sediments: Monitoring and modeling. J. Hydrol. 2008, 349, 214-229. [CrossRef]

82. Hall, J.K. The 25-m DTM (Digital Terrain Model) of Israel. Israel J. Earth Sci. 2008, 57, 145-147. [CrossRef]

83. Fischer, G.; Tubiello, F.N.; Van Velthuizen, H.; Wiberg, D.A. Climate change impacts on irrigation water requirements: Effects of mitigation, 1990-2080. Technol. Forecast. Soc. Chang. 2007, 74, 1083-1107. [CrossRef]

84. Doll, P.; Siebert, S. Global modeling of irrigation water requirements. Water Resour. Res. 2002, $38,1037$. [CrossRef]

85. Beltrán, J.M. Irrigation with saline water: Benefits and environmental impact. Agric. Water Manag. 1999, 40, 183-194. [CrossRef]

86. Bar-Tal, A.; Fine, P.; Yermiyahu, U.; Ben-Gal, A.; Hass, A. Practices that simultaneously optimize water and nutrient use efficiency: Israeli experiences in fertigation and irrigation with treated wastewater. In Managing Water and Fertilizer for Sustainable Agricultural Intensification; Drechsel, P., Heffer, P., Magen, H., Mikkelsen, R., Wichelns, D., Eds.; International Fertilizer Industry Association: Paris, France, 2015; pp. 209-241.

87. Darwish, T.; Atallah, T.; El Moujabber, M.; Khatib, N. Salinity evolution and crop response to secondary soil salinity in two agro-climatic zones in Lebanon. Agric. Water Manag. 2005, 78, 152-164. [CrossRef]

88. Hou, Z.; Chen, W.; Li, X.; Xiu, L.; Wu, L. Effects of salinity and fertigation practice on cotton yield and $15 \mathrm{~N}$ recovery. Agric. Water Manag. 2009, 96, 1483-1489. [CrossRef]

89. Moreira Barradas, J.M.; Abdelfattah, A.; Matula, S.; Dolezal, F. Effect of fertigation on soil salinization and aggregate stability. J. Irrig. Drain. Eng. 2014, 141, 5014010. [CrossRef]

90. Dudley, L.M.; Ben-Gal, A.; Lazarovitch, N. Drainage water reuse: Biological, physical, and technological considerations for system management. J. Environ. 2008, 37, S25-S35. [CrossRef] [PubMed]

91. Ayers, S.R.; Westcot, W.D. Water Quality for Agriculture; Food and Agriculture Organization of the United Nations: Rome, Italy, 1985.

92. Corwin, D.L.; Rhoades, J.D.; Šimůnek, J. Leaching requirement for soil salinity control: Steady-state versus transient models. Agric. Water Manag. 2007, 90, 165-180. [CrossRef]

93. Maas, E.V. Crop salt tolerance. In Agricultural Salinity Assessment and Management; Tanji, K.K., Ed.; ASCE Manuals and Reports on Engineering, No. 71; ASCE: New York, NY, USA, 1990; pp. 262-304.

94. Martin, D.L.; Gilley, J.R. Irrigation Water Requirements. In National Engineering Handbook; Part 623; USDA, Soil Conservation Service: Washington, DC, USA, 1993; p. 284.

95. Wu, J.; Vincent, B.; Yang, J.; Bouarfa, S.; Vidal, A. Remote Sensing Monitoring of Changes in Soil Salinity: A Case Study in Inner Mongolia, China. Sensors 2008, 8, 7035-7049. [CrossRef] [PubMed]

96. Xu, X.; Huang, G.; Qu, Z.; Pereira, L.S. Assessing the groundwater dynamics and impacts of water saving in the Hetao Irrigation District, Yellow River basin. Agric. Water Manag. 2010, 98, 301-313. [CrossRef]

97. Yu, R.; Liu, T.; Xu, Y.; Zhu, C.; Zhang, Q.; Qu, Z.; Liu, X.; Li, C. Analysis of salinization dynamics by remote sensing in Hetao Irrigation District of North China. Agric. Water Manag. 2010, 97, 1952-1960. [CrossRef]

98. Ren, D.; Xu, X.; Hao, Y.; Huang, G. Modeling and assessing field irrigation water use in a canal system of Hetao, upper Yellow River basin: Application to maize, sunflower and watermelon. J. Hydrol. 2016, 532, 122-139. [CrossRef] 
99. Cai, L.G.; Mao, Z.; Fang, S.X.; Liu, H.S. The Yellow River basin and case areas. In Water Saving in China, the Yellow River Basin: Issues and Decision Support Tools in Irrigation; Pereira, L.S., Cai, L.G., Musy, A., Minhas, P.S., Eds.; Agricultural Press: Beijing, China, 2003; pp. 13-34.

100. Chen, J.; Wang, F.; Meybeck, M.; He, D.; Xia, X.; Zhang, L. Spatial and temporal analysis of water chemistry records (1958-2000) in the Huanghe (Yellow River) basin. Glob. Biogeochem. Cycles 2005, 19, 1-24. [CrossRef]

101. Feng, Z.Z.; Wang, X.K.; Feng, Z.W. Soil N and salinity leaching after the autumn irrigation and its impact on groundwater in Hetao Irrigation District, China. Agric. Water Manag. 2005, 71, 131-143. [CrossRef]

102. Xiuling, F.S.C. Rationally utilizing water resources to control soil salinity in irrigation districts. In Proceedings of the Sustaining the Global Farm, Selected Papers from the 10th International Soil Conservation Organization Meeting, West Lafayette, IN, USA, 24-29 May 1999; pp. 1134-1138.

103. Jordán, M.M.; Navarro-Pedreño, J.; García-Sánchez, E.; Mateu, J.; Juan, P. Spatial dynamics of soil salinity under arid and semi-arid conditions: Geological and environmental implications. Environ. Geol. 2004, 45, 448-456. [CrossRef]

104. Hillel, D. Salinity Management for Sustainable Irrigation: Integrating Science, Environment, and Economics; World Bank Publications: Washington, DC, USA, 2000.

105. Salama, R.B.; Otto, C.J.; Fitzpatrick, R.W. Contributions of groundwater conditions to soil and water salinization. Hydrogeol. J. 1999, 7, 46-64. [CrossRef]

106. Ben-Gal, A.; Ityel, E.; Dudley, L.; Cohen, S.; Yermiyahu, U.; Presnov, E.; Zigmond, L.; Shani, U. Effect of irrigation water salinity on transpiration and on leaching requirements: A case study for bell peppers. Agric. Water Manag. 2008, 95, 587-597. [CrossRef]

107. Van Dam, J. Field-Scale Water Flow and Solute Transport: SWAP Model Concepts, Parameter Estimation, and Case Studies. Ph.D. Thesis, Wageningen University, Wageningen, The Netherlands, 2000.

108. Šimůnek, J.; Šejna, M.; van Genuchten, M.T. The HYDRUS-2D Software Package for Simulating Two-Dimensional Movement of Water, Heat and Multiple Solutes in Variably-Saturated Media; Version 2.0.; US Salinity Lab.: Riverside, CA, USA, 1999.

109. Šimůnek, J.; van Genuchten, M.T.; Šejna, M. Recent developments and applications of the HYDRUS computer software packages. Vadose Zone J. 2016, 15. [CrossRef]

110. Berezniak, A.; Ben-Gal, A.; Mishael, Y.; Nachshon, U. Manipulation of Soil Texture to Remove Salts from a Drip-Irrigated Root Zone. Vadose Zone J. 2017, 17. [CrossRef]

111. Lazarovitch, N.J.; Vanderborght, Y.J.; van Genuchten, M.T. The Root Zone: Soil Physics and Beyond. Vadose Zone J. 2018, 17. [CrossRef]

112. Pessarakli, M. Formation of Saline and Sodic Soils and Their Reclamation. J. Environ. Sci. Heal. Part A Environ. Sci. Eng. Toxicol. 1991, 26, 1303-1320. [CrossRef]

113. Valipour, M. Drainage, waterlogging, and salinity. Arch. Agron. Soil Sci. 2014, 60, 1625-1640. [CrossRef]

114. Feng, G.; Zhang, Z.; Wan, C.; Lu, P.; Bakour, A. Effects of saline water irrigation on soil salinity and yield of summer maize (Zea mays L.) in subsurface drainage system. Agric. Water Manag. 2017, 193, 205-213. [CrossRef]

115. Valipour, M. A Comparison between Horizontal and Vertical Drainage Systems (Include Pipe Drainage, Open Ditch Drainage, and Pumped Wells) in Anisotropic Soils. IOSR J. Mech. Civ. Eng. 2012, 4, 7-12. [CrossRef]

116. Benyamini, Y.; Mirlas, V.; Marish, S.; Gottesman, M.; Fizik, E.; Agassi, M. A survey of soil salinity and groundwater level control systems in irrigated fields in the Jezre'el Valley, Israel. Agric. Water Manag. 2005, 76, 181-194. [CrossRef]

117. Smedema, L.K.; Abdel-dayem, S.; Ochs, W.J. Drainage and agricultural development. Irrig. Drain. Syst. 2000, 14, 223-235. [CrossRef]

118. Kotb, T.H.S.; Watanabe, T.; Ogino, Y.; Tanji, K.K. Soil salinization in the Nile Delta and related policy issues in Egypt. Agric. Water Manag. 2000, 43, 239-261. [CrossRef]

119. Chaganti, V.N.; Crohn, D.M.; Šimůnek, J. Leaching and reclamation of a biochar and compost amended saline-sodic soil with moderate SAR reclaimed water. Agric. Water Manag. 2015, 158, 255-265. [CrossRef]

120. Rengasamy, P.; Olsson, K. Sodicity and soil structure. Aust. J. Soil Res. 1991, 29, 935-952. [CrossRef]

121. Brinck, E.; Frost, C. Evaluation of amendments used to prevent sodificationof irrigated fields. Appl. Geochem. 2009, 24, 2113-2122. [CrossRef] 
122. Qadir, M.; Qureshi, R.; Ahmad, N. Amelioration of calcareous saline-sodicsoils through phytoremediation and chemical strategies. Soil Use Manag. 2002, 18, 381-385. [CrossRef]

123. Ghafoor, A.; Gill, M.; Hassan, A.; Murtaza, G.; Qadir, M. Gypsum: Aneconomical amendment for amelioration of saline-sodic waters and soils, andfor improving crop yields. Int. J. Agric. Biol. 2001, 3, 266-275.

124. Oster, J.D.; Shainberg, I.; Abrol, I.P. Reclamation of salt-affected soil. Agric. Drain. Agron. Monogr. 1999, 38, 315-346.

125. Amezketa, E.; Aragues, R.; Gazol, R. Efficiency of sulfuric acid, mined gypsum, and two gypsum by-products in soil crusting prevention and sodic soilreclamation. Agron. J. 2005, 97, 983-989. [CrossRef]

126. Sadiq, M.; Hassan, G.; Mehdi, S.; Hussain, N.; Jamil, M. Amelioration ofsaline-sodic soils with tillage implements and sulfuric acid application. Pedosphere 2007, 17, 182-190. [CrossRef]

127. Qadir, M.; Oster, J.; Schubert, S.; Noble, A.; Sahrawat, K. Phytoremediation ofsodic and saline-sodic soils. Adv. Agron. 2007, 96, 197-247.

128. Rozema, J.; Flowers, T. Crops for a Salinized World. Science 2008, 322, 1478-1480. [CrossRef] [PubMed]

129. Chinnusamy, V.; Jagendorf, A.; Zhu, J.K. Understanding and improving salt tolerance in plants. Crop Sci. 2005, 45, 437-448. [CrossRef]

130. Lyra, D.A.; Ismail, S.; Butt, K.U.R.B.; Jed Brown, J. Evaluating the growth performance of eleven Salicornia bigelovii populations under full strength seawater irrigation using multivariate analyses. Aust. J. Crop Sci. 2016, 10, 1429-1441. [CrossRef]

131. Bashan, Y.; Moreno, M.; Troyo, E. Growth promotion of the seawater-irrigated oilseed halophyte Salicornia bigelovii inoculated with mangrove rhizosphere bacteria and halotolerant Azospirillum spp. Biol. Fertil. Soils 2000, 32, 265-272. [CrossRef]

132. Ravindran, K.C.; Venkatesan, K.; Balakrishnan, V.; Chellappan, K.P.; Balasubramanian, T. Restoration of saline land by halophytes for Indian soils. Soil Biol. Biochem. 2007, 39, 2661-2664. [CrossRef]

133. Campos, J.F.; Cara, B.; Pérez-Martín, F.; Pineda, B.; Egea, I.; Flores, F.B.; Fernandez-Garcia, N.; Capel, J.; Moreno, V.; Angosto, T.; et al. The tomato mutant ars1 (altered response to salt stress 1) identifies an R1-type MYB transcription factor involved in stomatal closure under salt acclimation. Plant Biotechnol. J. 2016, 14, 1345-1356. [CrossRef] [PubMed]

134. Cappelle, M.A.; Alspach, B.; Gilron, J.; Russell, C.; Davis, T.A. Enhancing Water Recovery Sustainably. Opflow 2015, 41, 24-26. [CrossRef]

135. Welle, P.D.; Medellín-Azuara, J.; Viers, J.H.; Mauter, M.S. Economic and policy drivers of agricultural water desalination in California's central valley. Agric. Water Manag. 2017, 194, 192-203. [CrossRef]

136. Rebhun, M. Desalination of reclaimed wastewater to prevent salinization of soils and groundwater. Desalination 2004, 160, 143-149. [CrossRef]

137. Silber, A.; Israeli, Y.; Elingold, I.; Levi, M.; Levkovitch, I.; Russo, D.; Assouline, S. Irrigation with desalinated water: A step toward increasing water saving and crop yields. Water Resour. Res. 2015, 51, 450-464. [CrossRef]

138. Oster, J.D. Irrigation with poor quality water. Agric. Water Manag. 1994, 25, 271-297. [CrossRef]

139. Jae-Kwon, S.; Won-Tae, S.; Su-Hwan, L.; Jin-Hee, R.; Jae-Young, C. Reclamation of a coastal reclaimed tidal land soil by gypsum and rice straw. Arch. Agron. Soil Sci. 2017, 63, 761-770.

140. Mlih, R.; Bol, R.; Amelung, W.; Brahim, N. Soil organic matter amendments in date palm groves of the Middle Eastern and North African region: A mini-review. J. Arid Land 2016, 8, 77-92. [CrossRef]

141. Minasny, B.; McBratney, A.B. Limited effect of organic matter on soil available water capacity. Eur. J. Soil Sci. 2018, 69, 39-47. [CrossRef]

142. Devkota, M.; Gupta, R.K.; Martius, C.; Lamers, J.P.A.; Devkota, K.P.; Sayre, K.D.; Vlek, P.L.G. Soil salinity management on raised beds with different furrow irrigation modes in salt-affected lands. Agric. Water Manag. 2015, 152, 243-250. [CrossRef]

143. Jenny, H. Factors of Soil Formation: A System of Quantitative Pedology; McGRAW-HILL Book Company: New-York, NY, USA, 1994.

(C) 2018 by the author. Licensee MDPI, Basel, Switzerland. This article is an open access article distributed under the terms and conditions of the Creative Commons Attribution (CC BY) license (http:/ / creativecommons.org/licenses/by/4.0/). 